\title{
Talking books for children's home use in a minority Indigenous Australian language context
}

\author{
Glenn Auld \\ Monash University
}

\begin{abstract}
Members of the Kunibídji community are the traditional owners of the lands and seas around Maningrida, a remote community in Northern Australia. Most of the 200 members of the Kunibídji Community speak Ndjébbana as their first language. This study reports on the complexities of transforming technology to provide Kunibídji children with access to digital texts at home. The printed Ndjébbana texts that were kept at school were transformed to Ndjébbana talking books displayed on touch screen computers in the children's homes. Some results of the children's interaction around these touch screens are presented as well as some quantitative results of the computer viewing in the homes. The processes of rejecting technological determinism, upholding linguistic human rights of speakers of minority languages and viewing technology as practice rather than a set of artefacts are discussed in this paper. The results of this study hightlight the need for speakers of minority Indigenous Australian languages to have access to texts in their threatened languages on technologies at home.
\end{abstract}

\section{Introduction}

When I first flew the 500 kilometres from Darwin to Maningrida, my knowledge of the community and surrounding Arnhem Land was limited. Although I knew I would be teaching Kunibídji children at primary school, I was not aware that Kunibídji children learnt English as a third or fourth language and preferred to speak their first language, Ndjébbana, at home. During my many years in the community I formed strong relationships with many members of the Kunibídji community. There are only 200 members of the Kunibídji community, making Ndjébbana a minority Indigenous Australian language. Their strong respect for the land, culture and language was complemented by the respect they showed to the Indigenous and non-Indigenous visitors living on their land. I write this article from the perspective of a non-Indigenous teacher and researcher who became interested in Kunibídji children's right to access Ndjébbana texts at home. 
When Kunibídji children enter school they learn to read and write Ndjébbana texts as part of the Ndjébbana Two Way Learning Program. By reading printed Ndjébbana texts when they first enter school, Kunibídji children make strong links to the social and cognitive practices of literacy which they can later draw upon when learning to read English. When I began teaching Kunibídji preschool aged children I was interested to know if the children wanted to read Ndjébbana texts at home. This was important to me as teacher. If they did not want to do read first language texts then why was I supporting these literacies at school? If they did want to read these texts, then why were all the Ndjébbana texts stored only at school? Ndjébbana texts were limited in the community and the idea of providing the children with access to the texts on computers emerged as a viable way of providing texts at home. This study reports the children's reaction when they were provided with access to Ndjébbana Talking Books (NTB) on touch screen computers at home.

\section{Linguistic human rights}

Pinker (1994) has suggested that 'the loss of a language is part of a more general loss being suffered by the world, the loss of diversity of all things' (p.261). While an approach to uphold the diversity of languages in the world is akin to language as an organism, Eisenlohr (2004) suggests that language loss is more to do with the 'perceived dangers to the reproduction of ethnic or other forms of groupness that often motivate activism on behalf of a less-used language' (p.23). Dixon (1980) has suggested 'if a minority group is to maintain its ethnic identity and social cohesion it must retain its language' (p.79).

Underpinning these concepts of group identity and language use in a minority Indigenous Australian language context is an individual's linguistic human rights. Linguistic human rights uphold the rights of individuals to have access to education in their preferred language. Linguistic majorities take it for granted that their education will be in the medium of their own language (Skutnabb-Kangas, 2000). This study upholds the linguistic human rights of Kunibídji children by improving their access to texts in their first language at home. In order to uphold the linguistic human rights of Kunibídji children, I aimed to challenge the status quo of Kunibídji homes devoid of Ndjébbana texts and computers. I was searching for evidence that would clarify the relative importance the children would place on access to NTB at home. The choices provided to the Kunibídji children to improve their access to NTB were a prime concern when conceiving this study. 


\section{Contested nature of literacy}

Street's (1984) autonomous and ideological models of literacy are particularly useful in positioning the NTB and the social practices of literacy surrounding their creation and use. In an autonomous approach to literacy, people are subjugated to the skills of decoding and coding texts, which is seen as literacy. The fact that the children had access to Ndjébbana texts only at school prior to this study suggests the school was supporting an autonomous approach to Ndjébbana print literacy.

The 'ideological' model of literacy, on the other hand, incorporates 'the site of tension between authority and power on one hand and individual resistance and creativity on the other' (Street, 1984). The ideological model of literacy operated on a two fronts in this study. First there was my individual resistance to the limited access the children had to texts in their first language. Had this not been the case I might have submitted to the authority and power of the school to continue the restricted access to the Ndjébbana texts to use in the classroom. The second ideological dimension to this study concerned the expected interactions of the children when viewing the NTB. The ways of knowing and ways of being that the children bring to the readings of the texts at home could provide important knowledge for effective classroom teaching. Even if the children reject the opportunities to read the NTB, they will expose their values and attitudes towards reading Ndjébbana texts.

The ideological approach to literacy is important where Indigenous languages are being mediated on new technologies. (Eisenlohr, 2004) has suggested that the 'predominant ideological formulations of the link between language and community play a crucial role in determining whether practices of digital mediation in a lesser-used language will promote off-line or off-screen routine use of the language' (p.37). In the case of Kunibídji children, Ndjébbana is their preferred language of communication, so the mediation of their lesser used language would be English. Nonetheless the ideological formations that link their use of Ndjébbana and their everyday social practices in the community will be enacted in the viewing of NTB at home.

\section{Primary and secondary discourses}

Gee (1996) uses the terms primary and secondary discourses to distinguish between home and school social practices. 'Primary discourses are those to which people are apprenticed early in life during their primary socialisation as members of particular families within their sociocultural settings' (Gee, 1996, p.137). Gee's (1996) concept of primary discourses is 
strongly linked to understandings of funds of knowledge. Moll, Amanti, Neff and Gonzalez (1992) have used the term funds of knowledge to describe the 'historically accumulated and culturally developed bodies of knowledge and skills essential for household or individual functioning and well-being' (p. 133). Secondary discourses, on the other hand, are 'those to which people are apprenticed as part of their socialisation within various local, state and national groups and institutions outside early home and peer-group socialisation' (Gee, 1996, p.137).

While the same people move in and out of these two contested spaces, I noted an absence of the Ndjébbana texts and computers in the primary discourses of members of the Kunibídji community. This absence of computers in the homes lead presents two important questions. Do the members of the Kunibídji not want computers at home? Do members of the Kunibídji want computers at home, but do not have the power to make it happen?

The presence or absence of technology in the children's homes was not as important as the ethical dilemma I faced when I began thinking about how far I could ethically influence the primary discourses of my students. I had to question what right had I, as a non-Indigenous outsider, to provide Kunibídji children with new technologies of apprenticeship in their family context? However in similar circumstances, I noticed that the school did not enter into a dialogue with members of the community when the Internet was being introduced.

As a way through this dilemma, I asked a few parents and Indigenous Australian educational workers who worked with me in the preschool, what they thought of the idea of their children being able to access Ndjébbana stories on computers at home. Their response was positive. They also highlighted that part of this response involved their respect for my relationship with their children. After being in the community for nearly ten years the ontological nature of their response was to be expected. Smith (1999, p.120) suggests that all sound participatory research practice should be based on a sense of 'respect'. The movement of computers from the school as a secondary discourse to the children's homes as their primary discourse was done out of my respect for the children's learning opportunities and their linguistic human rights.

Gee (1996) has stated that 'acquisition must (at least partially) precede learning; apprenticeship must precede overt teaching. Classrooms that do not properly balance acquisition and learning, and realise which is which simply privilege those students who have already begun the acquisition process outside the school' (p.139). I aimed to promote the children's acquisition of some of the social practices of reading Ndjébbana through 
the use of NTB. Hopefully the development of the skills at school could be continued in a more meaningful way. This study provided children with the opportunities to incorporate NTB in their funds of knowledge that they bring to school. At the same time I was open to the children and their parents rejecting the use of computers at home, in which case I could renegotiate the role of Ndjébbana literacy as an exclusive secondary discourse by the children.

\section{Evolution of technological literacies}

Another useful theoretical perspective for this study is the evolution of technological literacies as outlined by Bruce (1998), who suggested that literacy in relation to technologies develops over time in the following stages:

- Primitive symbol systems

- Complex oral language

- Manuscript literacy

- Print literacy

- Video literacy

- Digital/ multimedia/ hypertext literacy

- Virtual reality

The evolution of technological literacies proposed by Bruce (1998) is associated with the dominant literacy practices of many privileged speakers of majority languages in affluent societies. Kunibídji children have a different history of technological literacies associated with Ndjébbana to that presented above. A chronology of technological literacies used by Kunibídji children highlights this difference.

Before this study began, the chronology of Kunibídji technological literacies associated with Ndjébbana in home environments could be presented as follows:

- Complex oral language, ceremony, cultural artefacts, symbols (Kylelittle 1975; Doolan 1989)

- Ndjébbana print literacy began in 1975 (Mckay 2000)

There are several differences between the technological literacies associated with Ndjébbana and those identified by Bruce (1998). One major difference is the limited exposure to print literacy experienced by members of the Kunibídji community. As a consequence, they have had limited opportunities to develop the social practices associated with reading and writing in their first language. Another difference between the two evolutions of technological literacy is the limited access members of the 
community have had to graphic and digital texts in Ndjébbana. Kunibídji children have not had opportunities to integrate graphic and digital forms of Ndjébbana texts into their everyday social practices at home.

Transforming the printed Ndjébbana books to multimodal NTB was done to improve the children's access to the content of the texts. Nathan (2000) has suggested that the one-directional form of communication found in print makes knowledge cold and unchangeable to Indigenous people. Knowledge associated with primary discourses is often open to negotiation. In making the NTB accessible to Kunibídji children, the experience of accessing the texts needed to invite them to consider that there was no onus on the children to access the texts at home. Zammitt and Downes $(2002$, p.25) suggest that a feature of multimodal texts is their interconnectedness with the form, content and the possibilities of learning. The NTB were linked to make access to each text easier than physically selecting printed books.

Alternative technological evolutions to that proposed by Bruce (1998) and associated with literacies in minority Indigenous Australian languages are not exclusive to members of the Kunibídji community. Laughren (2000, p.1) suggests that, as the number of Indigenous Australian languages has decreased, those that remain have been represented in a variety of media. No doubt each of these media have a different set of technological literacies associated with their use and there is a variety of Indigenous chronologies associated with new technologies. Warschauer and Donaghy (1997), for example, have documented the use of a bulletin board system that provided meaningful language interaction between speakers of an Indigenous language who resided in a number of islands in Hawaii. As the majority of Indigenous people are multilingual (Skutnabb-Kangas 2000), it is not surprising that technological literacies will be borrowed from one language and applied to another. What underpins the use of new technologies in this study is a belief that contested literacy practices drive the evolution of new technological literacies. The home environment would be a prime place to see these contested practices in action.

\section{Methodology}

I knew that if the children were to be provided with access to the Ndjébbana stories at home I would need to intervene in the digitisation, as community members did not posses these skills at the time of this study. Bearing in mind that I was paid to teach the children and as a nonIndigenous person on Kunibídji land I was facing the same problem of intervention every day I taught a class of Kunibídji children. In controlling the design of the NTB, I intervened with a view to upholding the linguistic 
human rights of the children and overcoming a silence that they faced at home in their everyday social practice.

\section{The design of the Ndjébbana talking books}

The NTBs were developed in Macromedia Director, a multimedia authoring program. Each NTB simultaneously represent pictures, printed text and sound for each page of the book. Buttons are pressed to move between the pages of the text. As each page is opened, each word is highlighted as it is read. The Ndjébbana talking books were developed in the one file. Each Book accessed external sound and JPEG files, while the text files were imported into the Macromedia file. When construction of the texts was finished, the Macromedia file was saved as a projector, a self running application on any Macintosh or Windows computer. This way the children had access to some NTBs at school and at home. I developed the program that ran the NTBs using Lingo.

Warnick's (2002, p.10) concept of transparency was particularly useful in approaching the design of the NTB. Transparency is the condition in which the user forgets or is unaware of the presence of the medium (Warnick, 2002, p.10). The NTB were designed to be as transparent as possible to members of the Kunibídji community, while some aspects of the computer were redesigned to improve transparency.

The first element of transparency in the design of the NTB was that members of the Kunibídji community encountered only the Ndjébbana language when viewing the computer. There were no menus across the top of the screen in English or navigational buttons in English as part of the multimedia program. This transparent feature of the Ndjébbana talking books demonstrated to members of the Kunibídji community that computers could be used to support Ndjébbana acquisition and learning by the children. Speakers of Ndjébbana did not need to have an EnglishNdjébbana hybrid language experience when accessing texts in their first language. Importantly the NTB had transformed the computer from technology that supported English in the offices and school in Maningrida, to one that supported Ndjébbana in the homes of Kunibídji children.

A second transparent design feature of the NTB was a trace that was activated every time the children selected a text, turned a page of the text or quit the text. The trace was recorded on the hard drive of the computer as it displayed the choices made by the children. I entered this study gaining approval from the parents and members of the Kunibídji community to collect this quantitative data while the stories were being read. 
An third, important transparent feature implicit in the design of the NTB was that there was no need for a keyboard to access the texts. Keyboards are central to the affordance of most computers. The affordances of an object relates to the characteristics that make it obvious how it is to be used (Norman, 1988). Considering that most Kunibídji do not know how to read printed Ndjébbana texts, by removing the keyboard I was reducing the possibility of the keyboard being perceived by some members of the community as an inhibitor or constraint to the viewing of the NTB.

\section{The development of the Ndjébbana talking books}

In collaboration with members of the Kunibídji community we planned what NTB would be constructed. There were about 250 Ndjébbana printed texts that had been created since 1975 as part of the school's Ndjébbana Bilingual program. These texts formed the basis for construction of the NTB with community members. Some texts used old black and white drawings that were scanned into a computer and coloured. Other texts used digital pictures taken by the children during excursions. Some texts used digital pictures of the children acting out stories that had previously used black and white drawings. Some texts were created using digital images of everyday social practices experienced by the children. A range of texts were created in an attempt to represent the diverse social practices enacted by members of the Kunibídji community. When children went on homeland excursions as part of the Ndjébbana Two Way Learning program, the digital photos they took provided the basis for some new NTBs. Figure 1 shows an example of a page from one of these talking books. The photos taken by the children involved social practices that the children identified as important. As a result, the NTB archived older texts while including many of the latest stories the children had created in Ndjébbana as part of their learning at school.

Transforming the Ndjébbana printed texts to NTB drew on audio, visual and linguistic modes of representation. An important design element used in the talking books was sound. The inclusion of sound in the NTBs reflected the strong oral tradition amongst members of the Kunibídji community. When accessing the NTBs, the children could hear their relatives and known community members reading each page of the text. This was an attempt to make the knowledge in the texts inviting to Kunibídji children.

The use of sound and pictures in the texts meant that members of the Kunibídji community who were not print literate could contribute to the text production process. In some texts, adults who could not read were recorded after they repeated what another person had read. When children 
accessed these texts an adult who could not read Ndjébbana, but was well respected in the community read the texts to them.

Relston ká-rama ka-rénjdjeya míkkombo.

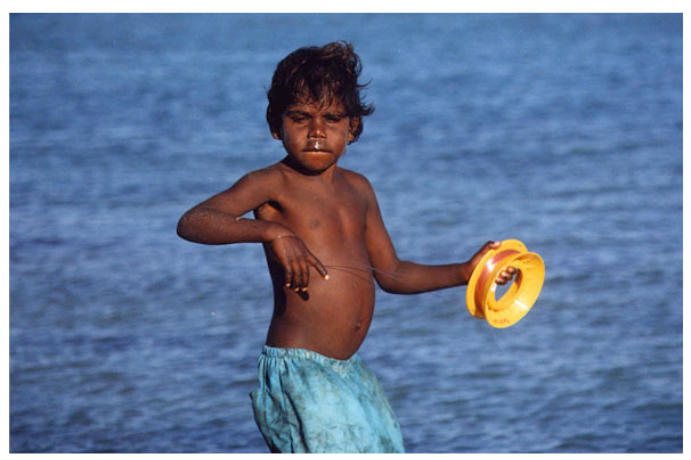

Figure 1: A page from a Ndjébbana talking book. The photo was taken on an excursion to land owned by some members of the Kunibídji community.

The reproduction of the text 'Kánbaya Nganéyabba Kayóra' (A Crocodile Went Along) demonstrated the kind of community involvement that could be achieved in the production of the NTBs. The original book, upon which this text is based, was made in 1980 when a member of the community told a literacy worker at the school a story about a crocodile. The literacy worker transcribed the story and the pictures were drawn to match the text. Many years later during this study, the literacy worker's daughter read the story back to the same community member who originally told the story. As this person repeated orally what was being read, her voice was recorded. These sounds were used in the Ndjébbana talking book that was originally told by her. When the children access this text they not only hear the book being read by somebody who cannot read printed Ndjébbana, but the words are highlighted as she says them.

In a productive effort by members of the Kunibídji community, nintey-six NTBs were created for the purposes of this study. To access each book the 
children had to click on a button that represented the title and front page of the book. Six buttons were presented on 16 different screens that the children could scroll between by clicking on arrows to move between the screens. An example of one of these screens is shown in Figure 2.

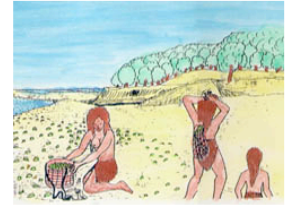

Wénjngala Njana Bayóndja
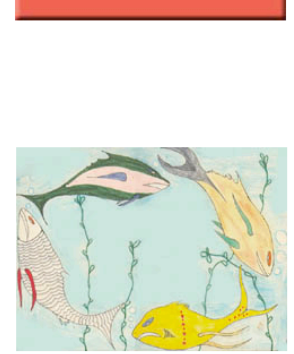

Yókkarra Ngarána

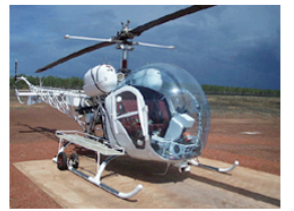

Djiya Ki-yirríya

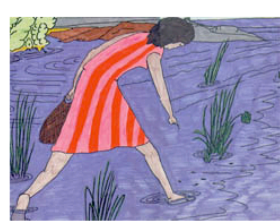

Karnáya Yakabála
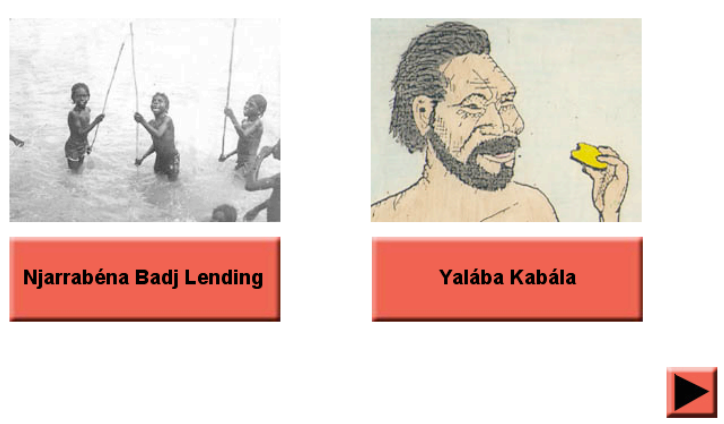

Figure 2: One of the 16 screens used to display links to the Ndjébbana talking books. This screen had a mixture of illustrations and scanned photos from previously produced Ndjébbana texts.

\section{Changing the technological practice}

There were two transformations of the computer that attempted to make the texts transparent. The first was relatively simple and involved unplugging the computer from the Internet. The online connectedness offered by computers in Maningrida did not appear to be the best way to support Kunibídji children's access to NTB at home. For a start there were no Ndjébbana texts accessible on the web. Very few homes had telephones and power was limited in some locations. There were constant issues of outstanding telephone accounts that made an online investigation of computer use a difficult issue to incorporate into the study. NTBs were designed in this study to support a specific set of literacies that were best accessed by Kunibídji children in an off line environment. 
Another transformation of the computer was the use of a touch screen. Touch screens operate by placing a touch sensitive material over the screen of the monitor. The touch screen hardware is linked to computer software that simulates a mouse click at the exact location where the screen is touched. This made the touch screen invisible to the members of the community as they accessed the texts. All of this technology was able to fit into an older style iMac computer, which meant the screen and the central processing unit were combined. This had the advantage of requiring only the power to be plugged into the back of the computer and no other leads were necessary for the touch screen to operate, which was particularly appropriate given the dusty conditions where the computers were located.

The use of touch sensitive screens is not a new technology in an Indigenous Australian context. Dench (1990) used touch sensitive boards with computers to support the learning of Wangkatja and English through a variety of interactive strategies. Touch sensitive boards were used in activities such as matching words and pictures, or creating short sentences by touching words displayed on the screen. The computer in Dench's (1990) study, however, took the role of a tutor. Taylor (1980, p.3) suggested that where computers are used to evaluate the students' interactions, computers take the role of a tutor. The focus of this study, however, was to use the technology to improve Kunibídji children's access to Ndjébbana texts. So the designs of the texts and the selective uses of computer technology that mediated the texts were attempts to keep the technology of this study transparent to Kunibídji children. The transparency of the Ndjébbana talking books in this research was critical since Kunibídji children would be acquiring the social practices that were associated with reading these texts. Unlike Dench's (1990) study, support to mediate the texts on the computer was not available from teachers or researchers.

The community was familiar with the technology that was to be used to present the tools of this research before the study began. When a touch screen computer was used for part of this study, most Kunibídji community members knew about the capacity of the computer to display interactive texts to the children. However for the first time the children had access to ninety six NTBs on the touch screen computers at home. The use of touch screen computers to mediate a relatively large number of NTBs for this study was a new experience for Kunibídji children. Importantly, the novelty of the media was not a central issue as the children had previous access to the touch screen computers.

The ninety six NTBs were placed on three touch screen computers. The children's interactions with one touch screen were recorded on video over a six month period during which time I collected about forty hours of video. I used a different computer each week during these trials to make 
sure the software and hardware was working so each computer could eventually be left in the homes. A typical literacy event with the a touch screen computer is presented in Figure 3.

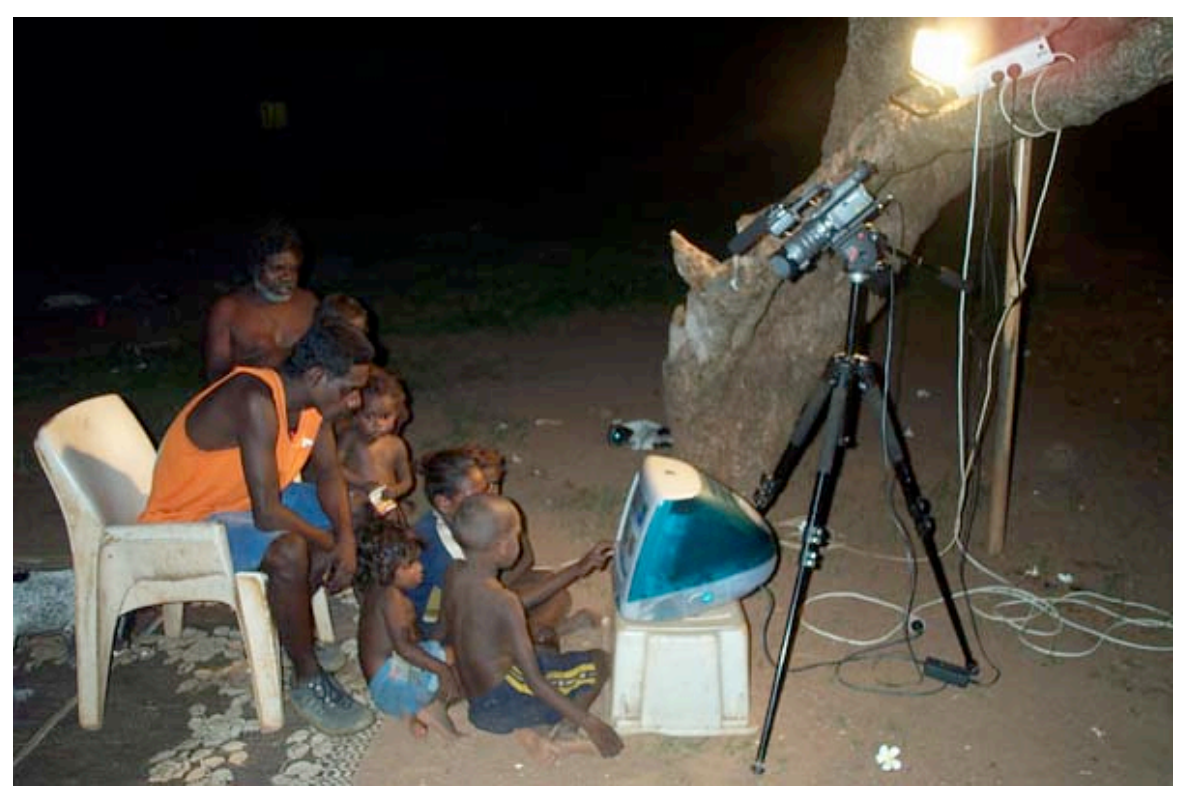

Figure 3: Members of the Kunibídji community viewing Ndjébbana talking books on a touch screen computer.

\section{Qualitative results}

As the NTBs read the stories to the children, the printed code in the texts was unpacked for the children. Considering that only a small number of the Kunibídji children can read Ndjébbana printed texts, this decoding of the sentences transformed the literacies needed to negotiate the meanings of the texts. The transformation from Ndjébbana printed books to NTBs places a focus on the children viewing rather than reading the texts.

The transparency of the technology supported the children's strong desire to access the NTBs. The children established turn taking routines to maintain some form of social order around the computer which was in high demand. In one instance the children could be seen using the same routine with a buffalo bone. The were sharing the meat on the bone while at the same time sharing access to the texts on the computer. Children appeared to move seamlessly between the routines, taking turns at touching the computer while others were taking turns at eating the bone. 
The fact that children share food, artefacts and time is not remarkable but the speed at which the NTBs were appropriated by the children is noteworthy.

An important feature of the technological transformation was that access to the texts supported the everyday social practices that the children were using around their homes. Technology was not determining human behaviour but rather fitting into the practices that already were operating in the children's homes.

The children talked together around the computer as the texts were being read to them. The discourse below was spoken amongst five children who were amongst the eleven children at the computer at the time. They said the following while choosing a new text to view in Ndjébbana language. The English translation of their interaction is provided below. I have put my interpretation of what the children meant in brackets after the English translation.

crocodile (choose the story with the crocodile in it)

pick the rain one (choose the story about the rain)

no pick the crocodile one

finish that, this mob this mob (don't look at any of those books, look at the book with these people in it)

he got the crocodile one (we are on the page with the crocodile book)

all the little kids (there is the book with all the little kids)

all the little kids are going to fight (in that book all the little kids are going to fight)

An important feature of this discourse was that it took less than five seconds. Although only one child was touching the computer, many others were participating in the choices of texts available that were showing to the child in control of the computer. The above discourse demonstrates that the children were using their knowledge of Ndjébbana to participate in the negotiation process of choosing the next text.

Kunibídji children also demonstrated their ability to be critical of normative behaviour while accessing the talking books. When Kunibídji children violated the norms of turn taking and page turning, for example, they were criticised by other children and adults near the computer. An example of this breakdown in turn taking behaviour was captured on one video. One of the older boys began violating his turn and after fifteen minutes one child complained, commenting that the older boy was 'acting like a Balanda'. This is a term used by members of the Kunibídji community for non-Indigenous Australians. It was used in this context in an attempt to lever 'Bradley' away from the computer and to give somebody else a turn. According to the child who made the comment, the 
only people who sit in front of computers for a long time are Balandas. The child was comparing Bradley's behaviour with the 'other' social practices of using computers exemplified by Balandas and using this comparison to insult Bradley's behaviour. Obviously this comment demonstrates that Kunibídji children know when a child is behaving badly. The comment also indicates how Kunibídji children can unpack other knowledge systems to criticise individuals deviating from normal behaviour.

\section{Quantitative results}

While the qualitative data in the video recording of the literacy events provided evidence of the children's desire to access the NTBs at home, the quantitative data of Kunibídji access to NTBs was recorded in my absence. The quantitative study was designed to gauge the desire by members of the Kunibídji community to access the Ndjébbana texts independent of my presence as a researcher.

The main evidence showing the Kunibídji children's desire to access the NTB came from the quantitative data collected from three touch screens located in different homes in the community. This quantitative data was generated as the children accessed the computer in my absence. While my intention was to provide unlimited access, I realised the children needed to negotiate logistical realities such as social relations and physical settings in order to watch the computer. The children's access to the NTB on the touch screen computers may have been limited by the absence of electricity in the house, the physical location of the computer, the social relations around the computer and unforseen technical problems, just to name a few. Given these limitations, the children's displayed their desire to access the Ndjébbana talking books. The interactions recorded by the computer are shown in Table 1.

Table 1: The number of taps recorded on the touch screen in the community

\begin{tabular}{|c|c|c|}
\hline Location & Days available & Number of taps \\
\hline 1 & 47 & 76,508 \\
\hline 2 & 15 & 20,763 \\
\hline 3 & 18 & 15,209 \\
\hline Total & 80 & 112,480 \\
\hline
\end{tabular}

While the data was being collected regular contact by the researcher was made with members of each house to check that the computer was still working and they were happy to continue with the study. The adults of many households told me that for the majority of the time the children were using the touch screens in the homes, with parents sometimes looking at the stories also. When the children came to school, usually accompanied 
by their parents, I was repeatedly informed that the children were using the computer at home. This information was offered without any prompting on my part as a teacher or researcher.

The large number of taps on the touch screen computers demonstrates a desire by Kunibídji children to access the NTB in their own homes. This was independent of any Balanda's understandings about the merits of acquiring Ndjébbana text based literacy. What adds to these results is that the children had access to the same NTB at school for several months before this study took place. This suggests that the results were not influenced by the novelty of the content of the NTB. As previously outlined, Kunibídji children also had access to touch screen computers displaying NTB in the community, so the technology was not new to them. What was new, however, was their unprecedented access to Ndjébbana texts in their own homes.

The large number of pages viewed by the children suggests that they wanted to access texts in their first language at home using technology that makes the narratives understandable. The large number of pages read by the children suggests that the combination of texts and technology used in this study was attractive to the children. The transformation of the technology played an important role in providing new choices to members of the Kunibídji community.

\section{Implications}

The implications of the children's responses to these texts are not limited to the local context of Maningrida. The following are ideas that might be used when considering other learning contexts where texts are produced and consumed for a local audience. Like many of the residents of Maningrida, the ideas presented below support the use of technology to enhance local literacy practices in the face of global changes.

\section{Rejecting technological determinism}

A deterministic or substantive theory of technology suggests that the social world is being restructured as an object of technological control that constitutes a new cultural system (Heidegger, 1977). According to Ellul (1964) a deterministic approach to technology continues to subjugate our humanity and determines how we behave. Supporters of a deterministic approach to technology often overlook the complex social environment that frames the access and use of technology by people. The findings of this study highlight the importance of trying to find technologies to match the social contexts where minority Indigenous Australian languages are 
spoken. The NTBs were not designed to determine the behaviour of Kunibídji children.

Similarly, Levy (1997a, p.xi) argues against being 'led purely by the capabilities of the latest technical innovation' when using computers to support language learning. By not being led by the latest technological innovation, which was the Internet at the time of this study, a space was provided to develop the NTBs. The results of this study suggest that Indigenous languages can be supported by technological configurations that are not the latest innovation, but are still highly effective in supporting their use. Considering the limited resources available in many remote locations where these languages are spoken, alternatives to the latest technology might be more practical in terms of economy and reliability.

Levy (1997b) suggests that the tool should match the task it is meant to support. When technology is used to support minority Indigenous Australian languages the primary task is to extend the choices the speakers have in their threatened languages. The choices available to the speakers of such languages should not be limited to the latest use of technology by speakers of majority languages. The tool in this case matched the need to provide children with access to texts at home.

\section{Issues of access and design}

In this study the children's desire to access the NTBs can be viewed from different perspectives. In an ideological perspective, the children's access to the NTB is important. Underpinning the children's desire to access the NTBs was their right and opportunity to access the texts. This opportunity was not provided for the children in a home context before this study began, because the Ndjébbana texts were not available in a form that made the meanings of the texts accessible to the children. Speakers of minority Indigenous Australian languages, however, have a right to access texts in their threatened language at home. When faced with unlimited access to texts in their first language, members of the Kunibídji community have recorded their preferences to access their language on new technologies. The 112,000 taps on the touch screen was their way of telling the world that their use of their language on new technologies was important to them. They were also telling the world that the content on the computer was engaging. An example of this is demonstrated in Figure 4.

This was interesting considering that the texts were designed primarily by an non-Indigenous person and developed with community involvement. The popularity of the NTBs would suggest that members of the Kunibídji community were pragmatic enough about the design of the NTBs in the absence of any other Ndjébbana text at home. The members of the 
Kunibídji community may value the contested nature of developing the texts and their consequent use more highly than any understanding of design. Feenberg (2002, p.14), on the other hand, suggests a focus should be placed on design, not just use of technology if people are to gain real power and self determination through technological practices. Maybe Feenberg's ideas are based on evidence where linguistic majorities take for granted that technologies will be designed to support the use of their dominant language.

\section{Barra-róddjiba barra-rówa barra-réndjeya míkkombo.}

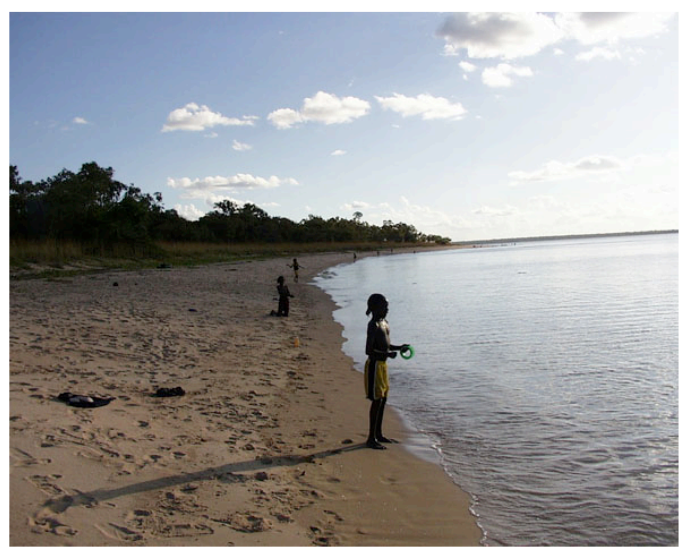

\section{Yaláwa}

Figure 4: A page from a Ndjébbana talking book recounting a camping trip to favourite fishing spot.

\section{Technology as a practice}

Another important understanding from this study comes from Frankin's (1990, p.12) work suggesting that technology is best seen as a practice. The importance of this understanding came to me when I realised the practices that were incorporated in the NTBs that were reproduced. Each text represented a unique set of collaborations between Indigenous and nonIndigenous people as they participated in the Ndjébbana Bilingual Program. The new texts made in this study, the NTBs, were not just artefacts but products that valued collaboration between Indigenous and 
non-Indigenous people. Perhaps part of the attraction the children found in the NTBs was the variety of these values embedded in the ninety-six texts.

The social aspects of technological use and design are more important than the artefact's attributes in a minority Indigenous Australian language context, where the purpose of the technology is to support the threatened language. An understanding of how the speakers of such languages approach the contested nature of new technological literacies will provide some key insights into the ontological ways of the participants.

Understandings of the participants have been a strong feature in effective literacy pedagogy. Street (2001) has suggested that effective literacy pedagogy begins by 'understanding the literacy practices target groups and communities are engaged in' (p.1), and learning how to design more culturally sensitive programs rather than programs based on what people are assumed to need (p.15).

Where technology is seen as a practice in a minority Indigenous Australian context, the practice might begin by obtaining evidence on text choices in their first language. While many speakers of minority Indigenous Australian languages do not have their language represented on new technologies at home, rudimentary texts such as the NTBs could be used to gauge the merits of further production. The evidence teachers glean from the children's technological practices with texts in their first language at home will have direct impact on the effectiveness of the literacy programs at school.

\section{Conclusion}

This study has reported on an innovative use of technology to provide marginalised Indigenous Australian children access to texts in their first language at home. In one sense the provision of this access was an end in itself in respecting the linguistic human rights of the child. The choices the children made were of secondary importance. In this study, however, the children's overwhelming response to viewing Ndjébbana texts at home, further justifies exploring new technological configurations in home contexts where minority Indigenous languages are spoken. Rather than determining what speakers of Indigenous Australian languages need in relation to technology, more work should be done to find which of the contested configurations of technology align with the home practices of the speakers. 


\section{Acknowledgement}

I acknowledge the support from members of the Kunibídji community for participating in the study and developing the texts used in this study. In particular, I acknowledge the assistance of Lena Djabbíba and Monica Wilton in supporting the production of the Ndjébbana talking books. The images in the talking books were used with permission from Maningrida Community Education Centre.

\section{References}

Bruce, B. C. (1998). New literacies. Journal of Adult and Adolescent Literacy, 42(1), 4649.

Doolan, J. K. (1989). The Founding of Maningrida. Darwin: Darwin Northern Territory Library Service (Occasional Papers No. 7).

Dench, P. (1990). Using computers to achieve literacy in minority languages. In A. McDougall \& C. Dowling (Eds), Computers and education (pp. 639-644). North Holland: Elsevier Science Publishers.

Dixon, R. M. W. (1980). The languages of Australia. Cambridge, UK; New York: Cambridge University Press.

Eisenlohr, P. (2004). Language revitalization and new technologies: Cultures of electronic mediation and the refiguring of communities. Annual Review of Anthropology, 33(1), 21-45.

Ellul, J. (1964). The technological society. New York: Vintage.

Feenberg, A. (2002). Transforming technology: A critical theory revisited. New York: Oxford University Press.

Franklin, U. (1990). The real world of technology. Montreal: CBC Enterprises.

Gee, J. P. (1996). Social linguistics and literacies: Ideology in discourses (2nd ed.). London: Falmer Press.

Heidegger, M. (1977). The question concerning technology. London: Harper.

Kyle-Little, S. (1957). Whispering wind. London: Hutchinson.

Laughren, M. (2000). Australian Aboriginal languages: Their contemporary status and functions. In R.M.W. Dixon \& B.J. Blake (Eds), The handbook of Australian languages: Volume 5 (pp. 1-32). Melbourne: Oxford University Press.

Levy, M. (1997a). Computer assisted language learning: Context and conceptualisation. Oxford: Clarendon Press. 
Levy, M. (1997b). A rationale for teacher education and CALL: The holistic view and its implications. Computers and the Humanities, (30)4, 293-302.

McKay, G. (2000). Ndjébbana. In R.M.W. Dixon \& B.J. Blake (Eds), The handbook of Australian languages: Volume 5 (pp. 155-354). Melbourne: Oxford University Press.

Moll, L., Amanti, C., Neff, D. \& Gonzalez, N. (1992). Funds of knowledge for teaching: Using a qualitative approach to connect homes to classrooms. Theory into Practice, 31(2), 132-140

Nathan, D. (2000). Plugging in Indigenous knowledge: Connections and innovations. Australian Aboriginal Studies, 2000(1\&2), 39-47.

Norman, D.A. (1988). The psychology of everyday things. New York: Basic Books.

Pinker, S. (1994). The language instinct (1st ed.). New York: W. Morrow and Co.

Skutnabb-Kangas T. (2000). Linguistic genocide in education or worldwide diversity and human rights. Mahwah, NJ: Lawrence Erlbaum Associates.

Smith, L. T. (1999). Decolonizing methodologies: Research and indigenous peoples. London: Zed Books.

Street, B. V. (1984). Literacy in theory and practice. Cambridge, UK; New York; Melbourne: Cambridge University Press.

Street, B. V. (2001). Introduction. In B. V. Street (Ed), Literacy and development: Ethnographic perspectives (pp. 1-17). London: Routledge.

Taylor, R. P. (1980). Introduction. In R. P. Taylor (Ed), The computer in the school: Tutor, tool, tutee (pp. 1-10) New York: Teachers College Press.

Warnick, B. (2002). Critical literacy in a digital era. Mahwah, NJ: Lawrence Erlbaum Associates.

Warschauer, M. \& Donaghy, K. (1997). A powerful voice of Hawaiian language revitalization. Computer Assisted Language Learning, 10(4), 349-361. [preprint verified 17 Feb 2007] http:/ / www.gse.uci.edu/faculty/markw/leoki.html

Zammit, K. \& Downes, T. (2002). New learning environments and the multiliterate individual: A framework for educators. Australian Journal of Language and Literacy, 25(2), 24-38.

Dr Glenn Auld, Faculty of Education, Peninsula Campus, Monash University, Frankston Victoria 3199, Australia.

Email: glenn.auld@education.monash.edu 